\title{
Prevalence of hepatitis $B$ and $C$ virus infections and their related risk factors in Libya: a national seroepidemiological survey
}

A.-N. Elzouki, ${ }^{1}$ M.-N. Smeo, ${ }^{2}$ M. Sammud, ${ }^{2}$ O. Elahmer, ${ }^{3}$ M. Daw, ${ }^{3}$ A. Furarah, ${ }^{3}$ A. Abudher and M.K. Mohamed $^{4}$

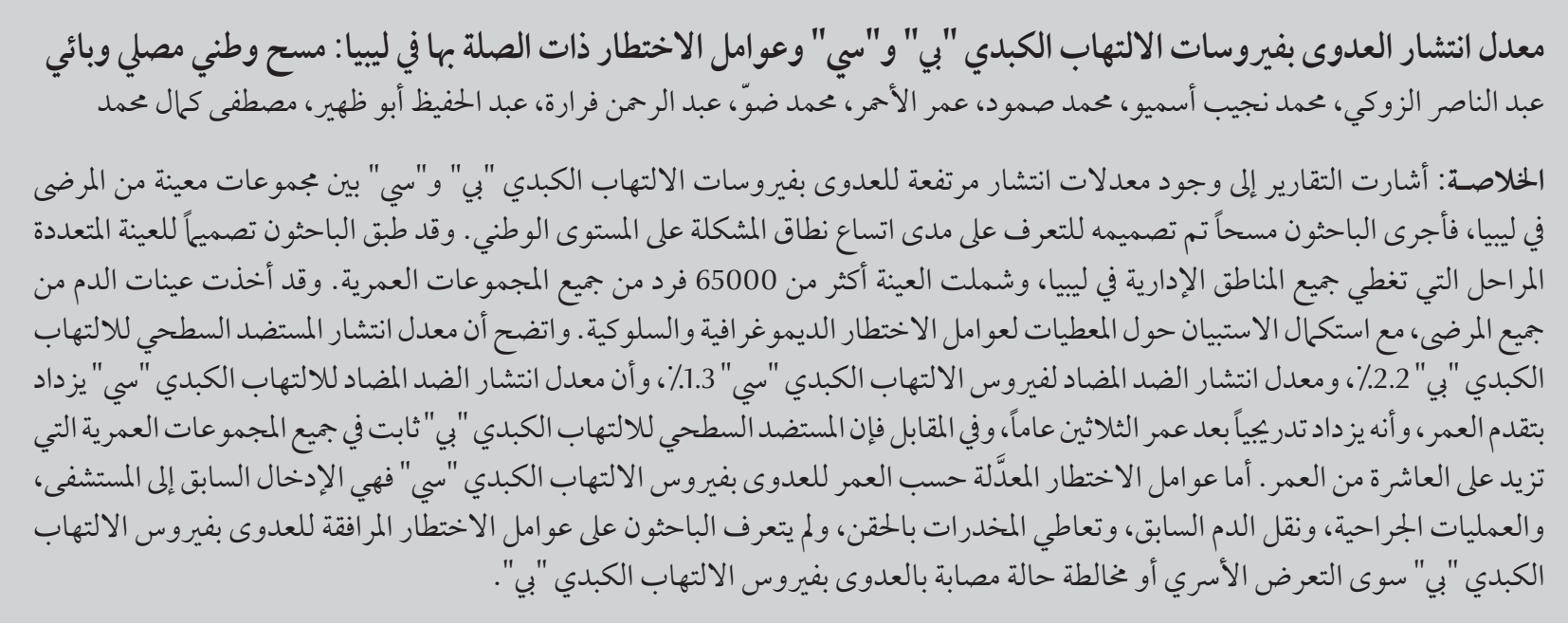

ABSTRACT A high prevalence of hepatitis B (HBV) and C virus (HCV) infections has been reported among specific patient groups in Libya; a survey was thus designed to determine the extent of the problem at the national level. A multistage sampling design covering all administrative areas of Libya was applied, covering > 65000 individuals of all age groups. All subjects gave a blood sample and completed a questionnaire on demographic and risk behaviour data. The prevalence of HBV surface antigen (HBsAg) and anti-HCV were $2.2 \%$ and $1.3 \%$ respectively. The prevalence of anti-HCV increased with age, rising gradually after age 30 years, in contrast to a stable prevalence of $\mathrm{HBsAg}$ in all age groups 10+ years. Age-adjusted risk factors for HCV infection were previous hospitalization, surgical operations, previous blood transfusions and intravenous drug use; for HBV infection only family exposure or contact with HBV case were identified.

Prévalence des infections par les virus de l'hépatite $B$ et $C$ et des facteurs de risque associés en Libye : enquête séro-épidémiologique nationale

RÉSUMÉ Une forte prévalence des infections par les virus de l'hépatite B et C a été signalée dans des groupes de patients spécifiques en Libye et une enquête a par conséquent été préparée pour évaluer l'étendue du problème à l'échelle nationale. Un plan d'échantillonnage à plusieurs degrés couvrant toutes les zones administratives de Libye a été appliqué, impliquant plus de 65000 personnes de tous les groupes d'âge. Tous les sujets ont fourni un échantillon de sang et rempli un questionnaire concernant leurs données démographiques et leur comportement à risque. La prévalence de l'antigène de surface du virus de l'hépatite B (AgHBs) et des anticorps anti-hépatite Cétait de 2,2 \% et 1,3\% respectivement. La prévalence des anticorps anti-hépatite C augmentait progressivement avec l'âge, enregistrant une progression à partir de 30 ans contrairement à la prévalence de l'AgHBs qui restait stable dans tous les groupes d'âge de plus de dix ans. Les antécédents d'hospitalisation, d'interventions chirurgicales, de transfusions sanguines et de consommation de drogue par voie intraveineuse étaient les facteurs de risque corrigés selon l'âge pour une infection par le virus de l'hépatite $C$, alors que pour l'infection par le virus de I'hépatite B, une exposition familiale ou le contact avec un cas infecté étaient les seuls facteurs identifiés. 


\section{Introduction}

Hepatitis B virus (HBV) and C virus $(\mathrm{HCV})$ infections are a major global public health problem warranting high priority efforts for prevention, control and treatment $[1,2]$. In developing countries the mode of transmission of these 2 bloodborne viruses tends to be from perinatal transmission or household contacts, while in developed countries sexual contact, shared needles among intravenous drug users and contaminated blood or organ transplants are more likely to be responsible for transmission. However, screening tests have reduced dramatically the risk of transmission worldwide [3-5].

Libya, a developing country of approximately 6 million people, belongs to the intermediate endemicity countries with a wide variance of seropositivity among different regions and populations. Previous studies of blood donors from serum screening in Libya revealed prevalence rates varying between $1.9 \%-5.8 \%$ for $\mathrm{HBV}$ and $1.2 \%-7.9 \%$ for HCV [6-11]. In one of these studies, a high prevalence of HCV infection in the apparently healthy Libyan population was reported (7.9\%) [9]. Nosocomial outbreaks of multiple bloodborne viral infections was reported in 2001 by Yerly et al. involving approximately 400 children. While all were infected with HIV, coinfection with $\mathrm{HCV}$ or $\mathrm{HBV}$ was found in $47 \%$ and $33 \%$ respectively after testing a subgroup of 148 children [10]. The prevalence of $\mathrm{HCV}$ antibodies among different populations in 1999-2001 was found to be $1.6 \%$ among healthy adults, $1.2 \%$ among blood donors, $2.0 \%$ among hospital health care workers, $10.8 \%$ in multiple blood transfusion patients and $20.5 \%$ among renal dialysis patients [11]. Furthermore, in Benghazi city the prevalence of anti-HCV in 153 chronic renal dialysis patients was found to be $21 \%$ [12]. It is well known that such a high prevalence of $\mathrm{HCV}$ infection could lead to a substantial increase in future morbidity and mortality from HCV-related diseases such as liver cirrhosis and hepatocellular carcinoma.

These high figures of HBV and $\mathrm{HCV}$ infection among different patients groups in Libya have raised questions about whether the general population has a similar high prevalence from sources as exposure to blood during the period before initiation of routine testing for blood units for anti-HCV in 1997. We conducted the present national seroepidemiological investigation to determine the prevalence and risk factors of $\mathrm{HBV}$ and HCV infection among the general population in Libya.

\section{Methods}

\section{Sample}

Sample size calculations were based on the prevalence of hepatitis B surface antigen (HBsAg) and $\mathrm{HCV}$ infection in previous studies in Libya. To detect a 2 -fold increase in prevalence among the lowest prevalence expected for HCV $(1 / 1000)$ in each age group as compared with the next age one a sample size of 25476 has a power of $80 \%$ (i.e. beta error of $<0.2$ ) to detect this difference at the alpha $=0.05$ level ( 1 -sided). This sample size allows for estimating a prevalence of 2/10 000 for HBsAg with a power of $>96 \%$. A total sample of 51000 would allow estimation of these parameters independently for males and females.

A multi-stage sampling technique was applied in the year 2005 to select a large, representative sample of sex and age groups from all administrative regions of Libya and to minimize refusals. The following age strata were targeted in each administrative region for both males and females:

- Pre-school children ( $<6$ years) at maternal and child care centres as well as other health facilities and child care centres.

- School-age children below university levels (6-18 years) at schools of the 3 levels (primary, preparatory and high schools).

- University age group for graduate and postgraduate students ( $19-45$ years) at university health service centres.

- Employment age (20-62 years), and above retired age ( $>62$ years) at schools for teachers, outpatient clinics at public sector facilities, outpatient clinics at general hospitals, work places at government facilities and inpatient health care facilities.

For regional representativeness, Libya was classified into 12 regions including all 32 administrative sections with a cluster sampling technique with population proportional to all age groups and both sexes. Several sampling frames were established in all targeted sectors in the 12 regions. The sampling units for schools were the class level in a frame including all schools and classes in each region. In health care facilities the unit was the health care centre in a frame including all health care facilities in the region. In administrative and employment places the unit was an office in a frame including all administrative buildings and offices in the region. The sample size for males and females and age strata was determined in each region proportional to regional population according to the latest national census in 2003-04. The target cluster sample was calculated for each sampling age and sex group in each region in proportion to its size within the region based on the national census.

The total sample in each region was set ahead of the survey and recruitment continued till the sampling teams fulfilled the required sample according to Table 1. Sample weighting was later performed and a weight was calculated according to age and sex within each region. 


\begin{tabular}{lcc}
\hline Table 1 Geographical sample allocation & \multicolumn{2}{c}{ Total sample } \\
\hline Province & No. & $\%$ \\
\hline Derna & 4996 & 7.6 \\
Aljabal Al-Akhdar & 5944 & 9.0 \\
Benghazi & 6938 & 10.6 \\
ljdabia & 4963 & 7.5 \\
Sirt & 3871 & 5.9 \\
Misrata & 4966 & 7.6 \\
Almergeb & 4913 & 7.5 \\
Tarhouna & 5023 & 7.6 \\
Tripoli & 8013 & 12.2 \\
Alzawia & 5022 & 7.6 \\
Aljabal Al-Garbi (Nafosa) & 5752 & 8.7 \\
Fezan & 5360 & 8.2 \\
Total & 65761 & 100.0 \\
\hline
\end{tabular}

\section{Data collection}

An anonymous questionnaire was filled out for each participant, including information on age, sex, education, residence and occupation. It also included lifetime history of major invasive exposures, use of recreational intravenous drugs and multiple sexual partners.

A 5-10 mL blood was collected on site and transported within a few hours to the local laboratory in a general hospital in the region for separating serum aliquots and stored in a $-20{ }^{\circ} \mathrm{C}$ deep freezer until testing. Serum samples were tested for anti-HCV antibodies by using a 3rd-generation microparticle enzyme immunoassay (Axsym System) (i.e. HCV EIA 3.0, Abbott Laboratories) and HBsAg (Axsym). Samples that initially gave a positive $\mathrm{HBsAg}$ and anti-HCV antibodies result were repeatedly tested for confirmation. Only cases that tested repeatedly positive were considered as positive for HBsAg and anti-HCV antibodies.

The study protocol and a questionnaire were approved by the Libyan $\mathrm{Na}$ tional Center for Disease Control ethics committee and an informed consent was prepared to be signed by the individual or a witness from the local health office before initiating collection of data or blood samples. Serum samples and associated demographic data were coded so that data were collected without any need for personal identifiers.

\section{Statistical analysis}

Data were coded and using a computer data entry program the database was cleaned and verified. Data were analysed by using the chi-squared test with Yates' correction or Student $t$-test for univariate analysis. Multivariate analysis was conducted using logistic regression, with anti-HCV serologic results as the dependent variable, using SPSS, version 17. Prevalence estimates were reported with $95 \%$ confidence intervals (CI) by using the Poisson distribution approximation. A type I error of alpha = 0.05 was assumed.

There was a good agreement between sample structure after weighting and population structure at all age groups for both males and females (data on request).

\section{Results}

The overall unweighted prevalence of anti-HCV was $1.2 \%$ (95\% CI: $1.1 \%-$ $1.3 \%)$, which rose to $1.3 \%$ after weighting. The overall prevalence of HBsAg for the whole sample was $2.2 \%$ (95\% CI: $2.1 \%-2.3 \%)$, with a significantly higher rate among males (2.6\%; 95\% CI: $2.4 \%-2.7 \%)$ than females (1.8\%; 95\% CI: 1.6\%-1.9\%). The risk for being HBsAg positive was 1.4 times higher among males than females (Table 2). The prevalence of anti-HCV increased with age rising gradually after the age of 30 years (from $0.7 \%-0.9 \%<30$ years up to $3.7 \% \geq 30$ years) in contrast to a stable prevalence of $\mathrm{HBsAg}$ in all age groups $10+$ years $(2.3 \%-2.7 \%)$ with a reduced prevalence probably due to vaccination of children among those < 10 years $(0.8 \%-0.9 \%)$.

The mean age of anti-HCV-positive individuals was 31.7 (SD 18.4) years and 35.6 (SD 20.9) years among females and males respectively, which

\begin{tabular}{|c|c|c|c|c|c|}
\hline \multirow[t]{3}{*}{ Sex } & \multirow{3}{*}{$\begin{array}{c}\text { Total sample } \\
\text { No. }\end{array}$} & \multicolumn{4}{|c|}{ Prevalence } \\
\hline & & \multicolumn{2}{|c|}{ HBsAg +ve } & \multicolumn{2}{|c|}{ Anti-HCV +ve } \\
\hline & & No. & $\%(95 \% \mathrm{Cl})$ & No. & $\%(95 \% \mathrm{Cl})$ \\
\hline Total & 65671 & 1431 & $2.2(2.1-2.3)$ & 780 & $1.2(1.1-1.3)$ \\
\hline Female & 32996 & 591 & $1.8(1.6-1.9)$ & 413 & $1.3(1.1-1.4)$ \\
\hline Male & 32765 & 840 & $2.6(2.4-2.7)^{\mathrm{b}}$ & 367 & $1.1(1.0-1.2)^{\mathrm{a}}$ \\
\hline
\end{tabular}

${ }^{a} P>0.05$ males vs females; ${ }^{b} P<0.001$ males vs females (OR 1.4; $95 \%$ CI: 1.3-1.6).

$\mathrm{Cl}=$ confidence interval. 


$\begin{aligned} & \text { Table } 3 \text { Mean age of hepatitis B surface antigen (HBsAg) and anti-hepatitis C virus (HCV) positive groups among males and } \\
& \text { females }\end{aligned}$
\begin{tabular}{lcccccc} 
Sex & \multicolumn{2}{c}{$\begin{array}{c}\text { Age (years) } \\
\text { HBsAg +ve }\end{array}$} \\
& \multicolumn{2}{c}{ Total sample } & \multicolumn{2}{c}{ Anti-HCV +ve } \\
Median & Mean (SD) & Median & Mean (SD) & Median & Mean (SD) \\
Total & 22 & $25.3(16.4)$ & 25 & $28.5(17.4)$ & 32 & $33.5(19.7)$ \\
Female & 22 & $24.7(15.5)$ & 23 & $26.3(16.8)$ & 30 & $31.7(18.4)$ \\
Male & 23 & $25.9(17.2)^{a}$ & 27 & $30.0(17.6)^{\text {a }}$ & 36 & $35.6(20.9)$ \\
\hline
\end{tabular}

${ }^{a} \boldsymbol{P}<0.001, t$-test for mean age.

$S D=$ standard deviation

was higher than for HBsAg-positive individuals, 26.3 (SD 16.8) years and 30.0 (SD 17.6) years among females and males respectively $(P<0.001)$ (Table 3). The mean age of anti-HCV-positive individuals was significantly higher than that for anti-HCV-negative individuals for both males (by almost 10 years) and females (by 7 years). The mean age of HBsAg-positive individuals was also significantly higher but to a lesser degree among females (by $<2$ years) and males (by $<4$ years).

Table 4 summarizes the seroprevalence ofHBsAg and anti-HCV antibodies among the general population according to demographic characteristics and risk factors. Although there was no significant difference between males and females in the prevalence of anti-HCV positivity, HBsAg was significantly higher in males than females $(P<0.001)$. The frequency of HBsAg and anti-HCV antibodies significantly increased with increasing age group $(P<0.001)$, and significantly decreased with increasing the level of education $(P<0.001)$. Among known risk factors, previous history of jaundice and history of contact with infected patients were significantly higher in both $\mathrm{HBsAg}$ and anti-HCV positives $(P<0.001$ respectively). In contrast, history of blood transfusion, previous hospital admission, previous surgical operation and history of skin piercing were the major risk factors for transmission of anti-HCV $(P<0.001$, for all comparisons).

As shown in Table 5, there was little difference in the estimated proportions of cases between males and females for
HCV but more than $60 \%$ of the estimated HBsAg cases were among males. More than $50 \%$ of the estimated HBsAg were $<30$ years and around $40 \%$ of HCV cases were also below that age. In terms of educational level and $\mathrm{HBV}$ and $\mathrm{HCV}$, the highest level of infection by both viruses was among illiterate individuals (weighted prevalence 2.6\% for HBsAg representing $12.3 \%$ of all estimated cases and $3.0 \%$ for anti-HCV antibodies representing $21.8 \%$ of all estimated cases).

There was a very clear-cut difference in the age distribution of HBsAg-positive cases at the 10-years age cut-off and of anti-HCV positive at the 30-years age cut-off. The estimated numbers of anti-HCV positive cases aged $30+$ years were $>40000$ and for HBsAg positive age $10+$ years were $>100000$ (Table 6).

\section{Regional variations in $\mathrm{HBsAg}$ and $\mathrm{HCV}$ prevalence}

As for regional differences in the prevalence of HBsAg and anti-HCV, there were significant variations from $0.6 \%$ in Misrata, up to $2.1 \%$ in Fezan for antiHCV and from 1.0\% in Benghazi and Aljabal Al-Akhdar to $6.6 \%$ in Sirt for HBsAg (Table 7).

\section{Risk factors for HCV infection}

Data from the present national survey were analysed by logistic binary regression analysis for HCV seropositivity to determine which risk factors were significantly associated with risk of infection. All invasive exposures were entered into the regression equation including dental treatment, traditional exposures such as tattooing and bloodletting or skin piercing. However, these were not significantly associated with increased risk of HCV infection. Similarly there was no significant difference of risk of infection according to sex. An increased risk was associated with increasing age for all subjects and among males and females (a significant risk for all age groups 50+ years compared with $<5$ years (data not presented). Among all subjects, hospitalization and surgical operation, blood transfusion, intravenous drug use and haemodialysis were all significantly associated with an increased age-adjusted risk compared with those not exposed. The increased risk for hospitalization and surgical operation and blood transfusion were modest (an increase of 29\%, 32\% and $48 \%$ respectively) with proportion of exposed in the community of $26 \%, 14.8 \%$ and $5.5 \%$ of all subjects respectively. The risk associated with intravenous drug use and haemodialysis were much higher (5.9 times and 3.5 times respectively), but their exposure frequency was only $0.1 \%$ of all subjects (Table 8 ).

Among males, similar increased risks were found but these were only statistically significant for intravenous hospitalization and diabetes treatment. Male drug abusers had an 9.4 times increased risk with an exposure frequency of $0.2 \%$ of all males. Hospitalization was significantly associated with increased risk of HCV infection of $39 \%$ with an exposure rate of $24.3 \%$, and diabetes treatment was associated with an increased risk of $53 \%$ with an exposure frequency of $3.7 \%$ among all males. The 


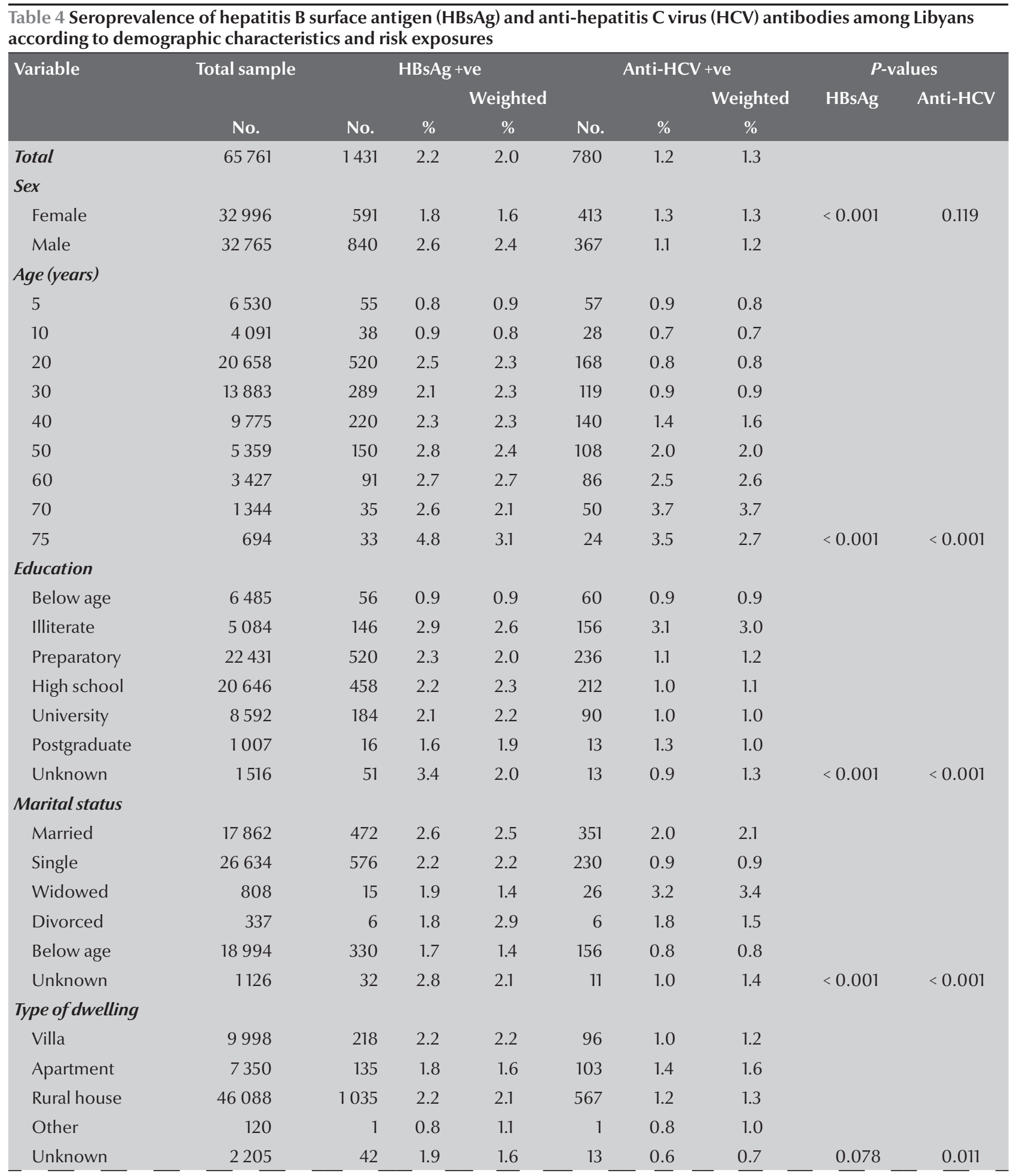

increased risk associated with surgical operation and blood transfusion did not reach statistical significance $(P$ $=0.071$ and $P=0.068$ respectively) . Among females, similar increased risks were found, but only blood transfusion was statistically significantly associated with increased risk of HCV (69\%). It was also clear that married women had a $69 \%$ increased risk of acquiring $\mathrm{HCV}$ (Table 8).

\section{Risk factors for HBV transmission}

Unlike HCV, there were no invasive risk factors associated with being
HBsAg-positive. The age-adjusted risk factors for HBV infection included only family exposure to HBV case or contact with HBV case with an increased risk of 2.1 (2.0 among females and 2.4 among males). Being vaccinated against $\mathrm{HBV}$ was protective and those who 


\begin{tabular}{|c|c|c|c|c|c|c|c|c|c|}
\hline \multirow[t]{3}{*}{ Variable } & \multirow{3}{*}{$\begin{array}{c}\text { Total sample } \\
\text { No. }\end{array}$} & \multicolumn{3}{|c|}{ HBsAg +ve } & \multicolumn{3}{|c|}{ Anti-HCV +ve } & \multicolumn{2}{|c|}{$P$-values } \\
\hline & & \multirow[b]{2}{*}{ No. } & \multicolumn{2}{|r|}{ Weighted } & \multirow[b]{2}{*}{ No. } & \multirow[b]{2}{*}{$\%$} & \multirow{2}{*}{$\begin{array}{c}\text { Weighted } \\
\%\end{array}$} & \multirow[t]{2}{*}{ HBsAg } & \multirow[t]{2}{*}{ Anti-HCV } \\
\hline & & & $\%$ & $\%$ & & & & & \\
\hline \multicolumn{10}{|l|}{ Clinical history } \\
\hline $\begin{array}{l}\text { Hospital } \\
\text { admissions }\end{array}$ & 16946 & 395 & 2.3 & 2.3 & 326 & 1.9 & 2.1 & 0.115 & $<0.001$ \\
\hline $\begin{array}{l}\text { Surgical } \\
\text { operations }\end{array}$ & 9586 & 233 & 2.4 & 2.3 & 218 & 2.3 & 2.6 & 0.077 & $<0.001$ \\
\hline $\begin{array}{l}\text { Blood } \\
\text { transfusion }\end{array}$ & 3557 & 74 & 2.1 & 2.0 & 96 & 2.7 & 2.8 & 0.681 & $<0.001$ \\
\hline $\begin{array}{l}\text { Dental } \\
\text { procedures }\end{array}$ & 23220 & 500 & 2.2 & 2.1 & 299 & 1.3 & 1.4 & 0.767 & 0.089 \\
\hline Skin piercing & 7451 & 189 & 2.5 & 2.4 & 130 & 1.7 & 1.9 & 0.073 & $<0.001$ \\
\hline Skin tattoo & 1243 & 36 & 2.9 & 2.5 & 22 & 1.8 & 2.3 & 0.532 & 0.283 \\
\hline IV drug use & 54 & 0 & 0.0 & 0.0 & 4 & 7.4 & 15.4 & 0.266 & $<0.001$ \\
\hline Illegal sex & 193 & 3 & 1.6 & 1.3 & 3 & 1.6 & 2.6 & 0.464 & 0.814 \\
\hline $\begin{array}{l}\text { HBV } \\
\text { vaccination }\end{array}$ & 13242 & 167 & 1.3 & 1.1 & 147 & 1.1 & 1.0 & $<0.001$ & 0.376 \\
\hline HBV contact & 1423 & 57 & 4.0 & 3.8 & 26 & 1.8 & 2.6 & $<0.001$ & 0.006 \\
\hline $\begin{array}{l}\text { History of } \\
\text { jaundice }\end{array}$ & 2421 & 88 & 3.6 & 3.6 & 51 & 2.1 & 2.5 & $<0.001$ & $<0.001$ \\
\hline
\end{tabular}

$I V=$ intravenous.

were vaccinated had a $44 \%$ lower risk of being infected (38\% among females and $49 \%$ among males) (Table 9).

\section{Discussion}

The present study reports the results of a national seroepidemiologic study in Libya on the prevalence of HBV and $\mathrm{HCV}$ infections and the related risk factors. Previous studies in Libya were based on selected populations such as hospitalized patients, health care workers and blood donors. Blood donor groups are usually young male adults, hence the seroprevalence in females and other age groups such as children and elderly people have not previously been estimated. The present study is the first survey of a representative, random, community-based sample of the general population of Libya. It is unique because a large sample size was tested (65 761), the evaluation was conducted in 12 distinct administrative regions of the country, the study comprised all age groups of both sexes in the Libyan general population and the risk factors for transmission for both HBV and HCV infections were identified. A multi-stage sampling technique was applied and the high participation rate from all age groups of both sexes in all administrative regions of Libya suggests the absence of selection bias and may provide an accurate assessment of HBsAg and anti-HCV prevalence and their associated risk factors in this developing country.

Since 1997 blood units were routinely examined for anti-HCV in all blood banks in Libya, which should reduce the transmission through blood transfusion. The relatively low overall prevalence of anti-HCV antibodies (1.3\%) among Libyans is still higher than Canada (0.8\%), Australia (1.1\%) and some western European countries including France (1.1\%) and Germany (0.6\%) [13-17] and is close to that reported from large studies of the general population in the United States of America $(1.8 \%-2.2 \%)[18-21]$ and much lower than the figures reported for Pakistan (5\%-7\%) [22,23] and Egypt (22\%) [24], a neighbouring country with a high movement of workers every year. The results of this study also are consistent with previously published studies of selected Libyan populations [6-11]. The relatively low level of $\mathrm{HCV}$ infection among the general population in this country can be contrasted with the high prevalence among those who reported use of intravenous drugs (15.4\%) and may suggest that this route of transmission is potentially an important risk factor for future transmission of HCV in Libya, as in the USA where it is the major mode of HCV transmission [25-28].

The prevalence of anti-HCV antibodies increased with age, rising gradually after the age of 30 years (from $0.7 \%-0.9 \%$ at age $<30$ years up to $3.7 \%$ at $30+$ years). This suggests that $\mathrm{HCV}$ 


\begin{tabular}{|c|c|c|c|c|}
\hline \multirow[t]{2}{*}{ Variable } & \multicolumn{2}{|c|}{ Estimated national HBSAg +ve } & \multicolumn{2}{|c|}{ Estimated national $\mathrm{HCV}+\mathrm{ve}$} \\
\hline & No. & $\%$ & No. & $\%$ \\
\hline Total & 107848 & 100.0 & 68275 & 100.0 \\
\hline \multicolumn{5}{|l|}{ Sex } \\
\hline Female & 42297 & 39.2 & 34845 & 51.0 \\
\hline Male & 65551 & 60.8 & 33430 & 49.0 \\
\hline \multicolumn{5}{|l|}{ Age (years) } \\
\hline 5 & 4861 & 4.5 & 4699 & 6.9 \\
\hline 10 & 4110 & 3.8 & 3881 & 5.7 \\
\hline 20 & 26148 & 24.2 & 8889 & 13.0 \\
\hline 30 & 26153 & 24.2 & 10147 & 14.9 \\
\hline 40 & 20139 & 18.7 & 13966 & 20.5 \\
\hline 50 & 11436 & 10.6 & 9738 & 14.3 \\
\hline 60 & 6856 & 6.4 & 6633 & 9.7 \\
\hline 70 & 3613 & 3.4 & 6415 & 9.4 \\
\hline 75 & 4532 & 4.2 & 3907 & 5.7 \\
\hline \multicolumn{5}{|l|}{ Education } \\
\hline Below age & 4957 & 4.6 & 5235 & 7.7 \\
\hline Illiterate & 13318 & 12.3 & 14850 & 21.8 \\
\hline Preparatory & 34927 & 32.4 & 20685 & 30.3 \\
\hline High school & 34389 & 31.9 & 17214 & 25.2 \\
\hline University & 16118 & 14.9 & 7544 & 11.0 \\
\hline Postgraduate & 1769 & 1.6 & 981 & 1.4 \\
\hline Unknown & 2370 & 2.2 & 1766 & 2.6 \\
\hline \multicolumn{5}{|l|}{ Marital status } \\
\hline Married & 39844 & 36.9 & 32605 & 47.8 \\
\hline Single & 42551 & 39.5 & 17845 & 26.1 \\
\hline Widowed & 1425 & 1.3 & 3403 & 5.0 \\
\hline Divorced & 913 & 0.8 & 470 & 0.7 \\
\hline Below age & 21434 & 19.9 & 12828 & 18.8 \\
\hline Unknown & 1681 & 1.6 & 1124 & 1.6 \\
\hline \multicolumn{5}{|l|}{ Type of dwelling } \\
\hline Villa & 13545 & 12.6 & 6944 & 10.2 \\
\hline Apartment & 10491 & 9.7 & 10480 & 15.3 \\
\hline Rural house & 80646 & 74.8 & 49398 & 72.4 \\
\hline Other & 118 & 0.1 & 104 & 0.2 \\
\hline Unknown & 3048 & 2.8 & 1349 & 2.0 \\
\hline
\end{tabular}

screening needs to be targeted on people aged $35+$ years old.

Although the results of the present study did not show a significant difference in the prevalence of anti-HCV antibodies according to sex, a higher prevalence of $\mathrm{HBsAg}$ in males and older ages was detected. The infection rate was higher in individuals aged $10+$ years and was more obvious at age $75+$ years, with a prevalence of $3.1 \%$. Individuals in the older age groups were most likely to have been exposed to $\mathrm{HBV}$ infection before the risks were well recognized, through hospital care, exposure to blood transfusion and blood products or family contacts. On the other hand, the lower HBsAg prevalence in individuals aged $<20$ years $(0.8 \%-0.9 \%)$ was probably due to the universal vaccination programme of newborns and adolescents against hepatitis B in Libya since 1992 according to World Health Organization criteria.

The present study showed that close contact with infected family members, particularly the mother, was probably 


\begin{tabular}{|c|c|c|c|c|c|}
\hline \multirow[t]{2}{*}{ Variable } & Sample & Total & $\begin{array}{l}\text { Estimated in } \\
\text { population }\end{array}$ & $\begin{array}{l}\text { Weighted } \\
+ \text { +ve }\end{array}$ & OR $(95 \% \mathrm{Cl})$ \\
\hline & No. & No. & No. & $\%$ & \\
\hline HCV estimated national caseload & & & & & $2.5(2.5-2.6)$ \\
\hline Age $<30$ yrs & 43240 & 352 & 25786 & 0.8 & \\
\hline Age $30+y r s$ & 22521 & 428 & 42489 & 2.0 & \\
\hline Total & 65761 & 780 & 68275 & 1.3 & \\
\hline HBV estimated national caseload & & & & & $3.3(3.2-3.3)$ \\
\hline Age $<10$ yrs & 76 & 9459 & 7006 & 0.7 & \\
\hline Age $10+$ yrs & 1355 & 56302 & 100842 & 2.3 & \\
\hline Total & 1431 & 65761 & 107848 & 2.0 & \\
\hline
\end{tabular}

$O R=$ odds ratio $; C I=$ confidence interval.

a major source of HBV infection, suggesting that intrafamiliar transmission is a significant risk factor. Screening of family members in direct contact with infected patients and subsequent vaccination is needed to minimize intrafamiliar transmission of HBV.

Comparison of invasive exposures between HBsAg-positive and -negative individuals did not reveal any factors that were significantly associated with HBV infection, except having family contact with an HBV-infected person and previous history of jaundice. In addition, this study did not find dental procedures or tattooing to be associated with transmission of $\mathrm{HCV}$. However, body piercing was a statistically significant risk factor for $\mathrm{HCV}$ but not for HBV transmission. HCV was significantly associated with a history of hospital admissions, surgical operations and blood transfusions, with prevalence rates among exposed individuals of at least twice the general population rate. Haemodialysis was reported among a very small number of individuals, which did not allow for a sufficient power for detecting its risk. The above findings may suggest that nosocomial infection may have an important role in transmission of $\mathrm{HCV}$ infection in a considerable number of individuals in Libya. Contaminated injection equipment seems to be the major risk factor for $\mathrm{HCV}$ infection in many developing countries. In Egypt, the country with the highest reported prevalence of $\mathrm{HCV}$ in the world, transmission has been attributed to contaminated glass syringes used in nationwide schistosomiasis treatment campaigns from 1960 to 1987 [23]. A high prevalence of HCV (31.1\%) has been also reported from India among patients receiving multiple injections to treat leishmaniasis [29] and among

\begin{tabular}{|c|c|c|c|c|c|}
\hline \multirow[t]{3}{*}{ Province } & \multirow{3}{*}{$\begin{array}{c}\text { Total sample } \\
\text { No. }\end{array}$} & \multicolumn{2}{|c|}{$\mathrm{HCV}$} & \multicolumn{2}{|c|}{ HBsAg } \\
\hline & & Weighted & Estimated +ve & Weighted & Estimated +ve \\
\hline & & $\%$ & No. & $\%$ & No. \\
\hline Derna & 308178 & 1.77 & 5467 & 1.59 & 4904 \\
\hline Aljabal Al-Akhdar & 335025 & 0.86 & 2877 & 1.00 & 3364 \\
\hline Benghazi & 656083 & 1.32 & 8686 & 1.04 & 6810 \\
\hline Igdabia & 208044 & 1.30 & 2703 & 1.35 & 2811 \\
\hline Sirt & 132174 & 0.99 & 1314 & 6.61 & 8743 \\
\hline Misrata & 512532 & 0.59 & 3042 & 1.73 & 8870 \\
\hline Almergeb & 203320 & 1.36 & 2759 & 1.43 & 2914 \\
\hline Tarhouna & 200523 & 1.20 & 2397 & 3.42 & 6858 \\
\hline Tripoli & 1422204 & 1.40 & 19854 & 2.27 & 32316 \\
\hline Alzawia & 541136 & 1.32 & 7150 & 2.42 & 13089 \\
\hline Aljabal Al-Garbi & 434406 & 1.10 & 4768 & 2.25 & 9760 \\
\hline Fezan & 348606 & 2.08 & 7258 & 2.13 & 7409 \\
\hline Total & 5302231 & 1.29 & 68275 & 2.03 & 107848 \\
\hline
\end{tabular}


논현

啇

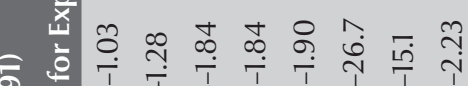

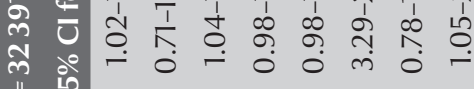
II

$\frac{y}{\frac{y}{5}}$

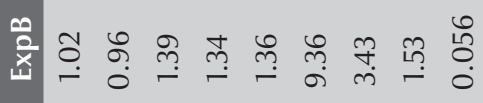

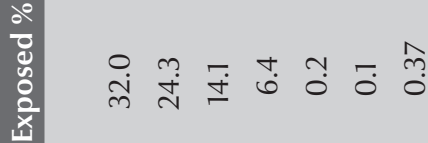

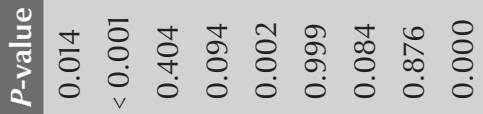

อิ

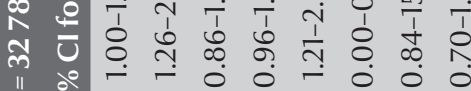

5 เे

y

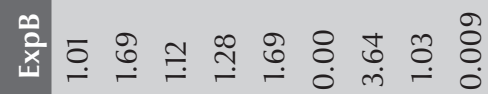

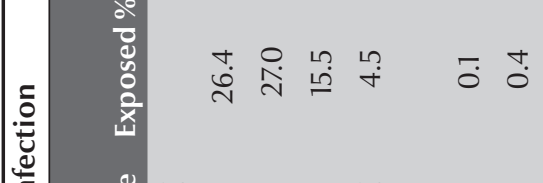

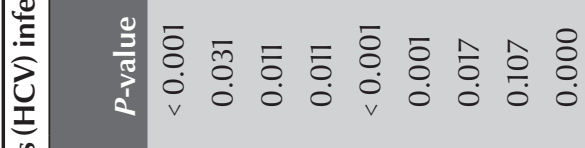

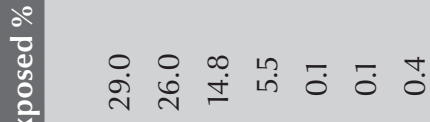

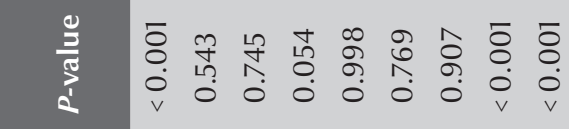

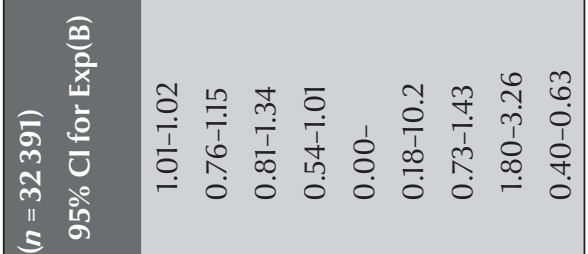

$\frac{\sqrt{\frac{y}{\pi}}}{2}$

商

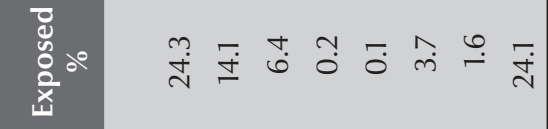

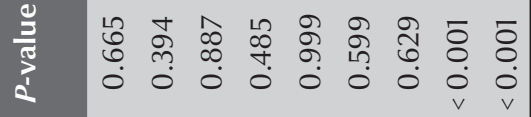

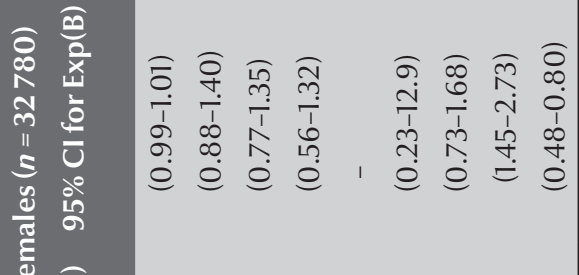

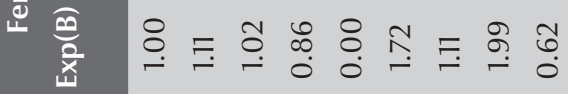

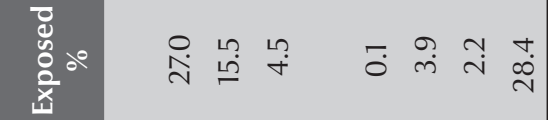

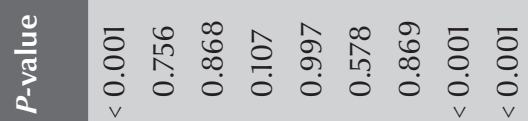

$\widehat{\frac{0}{0}}$

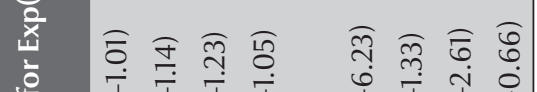

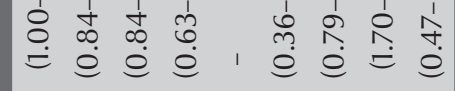

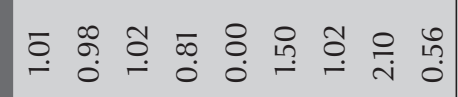

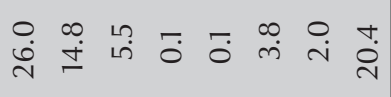

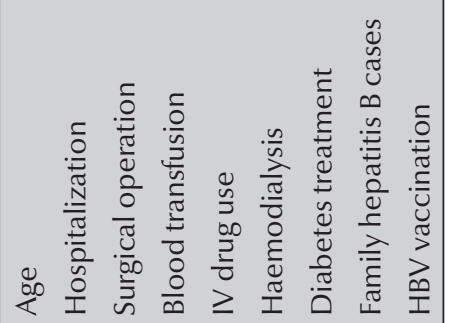


individuals with frequent visits to unlicensed practitioners [30] as well as among those with history of therapeutic injections using reusable syringes [31].

Sexual contact could also be a source of infection, although this was not detected in this national survey data analysis. However, HCV infections in some population groups may be due to high-risk sexual activity (e.g. multiple partners) similar to the findings of studies other countries [32-34].

In conclusion, the results of this general population-based survey suggest the need for continuous implementation of stringent measures for prevention and control of these infections in Libya, including screening and vaccination focused on high-risk groups, such as contacts for HBV cases. The higher prevalence of $\mathrm{HCV}$ infection in older age groups suggests that the Center for Disease Control of Libya needs to implement a targeted risk-based HCV screening programme for persons who are $35+$ years of age for early detection and specific treatment of this insidious infection. Even though the risk of HCV infection was relatively low compared with that of $\mathrm{HBV}$, the future health care burden of prior HCV infections in Libya could be substantial in the general community.

\section{Acknowledgements}

The authors would like to thank the laboratory staff at the National Center for Disease Control of Libya, in particular F. Alkatali, W. Elkayekh and A. Alhadi, for their technical support.

Funding: Financial support was provided by the National Center for Disease Control of Libya.

Competing interests: None declared.

\section{References}

1. Lavanchy D. Hepatitis B virus epidemiology, disease burden, treatment, and current and emerging prevention and contro measures. Journal of Viral Hepatitis, 2004, 11:97-107.

2. Wong W, Terrault N. Update on chronic hepatitis C. Clinical Gastroenterology and Hepatology, 2005, 3:507-520.

3. Perrillo RP. Hepatitis B: transmission and natural history. Gut, 1993, 34(Suppl.):S48-S49.

4. Alter MJ. Epidemiology of hepatitis C in the West. Seminars in Liver Disease, 1995, 15:5-14.

5. Di Bisceglie AM, Hepatitis C. Lancet, 1998, 351:351-355.

6. Elzouki A-N. Hepatitis B infection in Libya: The magnitude of the problem. Libyan Journal of Infectious Diseases, 2008, 2:1-4.

7. Elzouki A-N et al. Surface antigen in Libya: poor performance of reverse passive latex agglutination test. Journal of the Bahrain Medical Society, 1994, 6:57-60.

8. Zaied A, Elneihoum A, Elzouki A. Routine screening for antiHIV antibodies, hepatitis B surface antigen and anti-hepatitis $\mathrm{C}$ antibodies among general hospital in-patients. Jamahyria Medical Journal, 2003, 4:21-25.

9. Saleh MG et al. High prevalence of hepatitis $C$ virus in the normal Libyan population. Transactions of the Royal Society of Tropical Medicine and Hygiene, 1994, 88:292-294.

10. Yerly $\mathrm{S}$ et al. Nosocomial outbreak of multiple bloodborne viral infections. Journal of Infectious Diseases, 2001, 184:369-372.

11. Daw MA et al. Prevalence of hepatitis $C$ virus antibodies among different populations of relative and attributable risk. Saudi Medical Journal, 2002, 23:1356-1360.

12. Elzouki A-N et al. Prevalence of anti-hepatitis $\mathrm{C}$ virus antibodies and hepatitis $C$ virus viraemia in chronic haemodialysis patients in Libya. Nephrology, Dialysis, Transplantation, 1995, 10:475-476.

13. Shepard CW, Finelli L, Alter MJ. Global epidemiology of hepatitis C virus infection. Lancet Infectious Diseases, 2005, 5:558-567.

14. Zou S, Tepper M, El Saadany S. Prediction of hepatitis C burden in Canada. Canadian Journal of Gastroenterology, 2000, 14:575-580.

15. Law MG et al. Modelling hepatitis $C$ virus incidence, prevalence and long-term sequelae in Australia, 2001. International Journal of Epidemiology, 2003, 32:717-724.
16. Desenclos JC. Epidemiologie de I'hepatite C. [Epidemiology of hepatitis C]. La Revue du Praticien, 2000, 50:1066-1070.

17. Palitzsch KD et al. Prevalence of antibodies against hepatitis $C$ virus in the adult German population. European Journal of Gastroenterology \& Hepatology, 1999, 11:1215-1220.

18. Alter $\mathrm{MJ}$ et al. The prevalence of hepatitis $C$ virus infection in the United States, 1988 through 1994. New England Journal of Medicine, 1999, 341:556-562.

19. Hyams KC, Struewing JP, Gray GC. Seroprevalence of hepatitis A, B, and C in a United States military recruit population. Military Medicine, 1992, 157:579-582.

20. Seeff LB et al. 45-year follow-up of hepatitis $C$ virus infection in healthy young adults. Annals of Internal Medicine, 2000, 132:105-111.

21. Hyams KC, Palinkas LA, Burr RG. Viral hepatitis in the US Navy, 1975-1984. American Journal of Epidemiology, 1989, 130:319-326.

22. Ali A et al. Prevalence of active hepatitis c virus infection in district Mansehra Pakistan. Virology Journal, 2010, 7:334-338.

23. Frank $\mathrm{C}$ et al. The role of parenteral antischistosomal therapy in the spread of hepatitis C virus in Egypt. Lancet, 2000, 355:887-891.

24. Waheed $Y$ et al. Hepatitis $C$ virus in Pakistan: a systematic review of prevalence, genotypes and risk factors. World Journal of Gastroenterology, 2009, 15:5647-5653.

25. Outbreak of hepatitis $\mathrm{C}$ associated with intravenous immunoglobulin administration-United States, October 1993-June 1994. Morbidity and Mortality Weekly Report, 1994, 43:505-509.

26. Donahue JG et al. The declining risk of post-transfusion hepatitis C virus infection. New England Journal of Medicine, 1992, 327:369-373.

27. Schreiber GB et al. The risk of transfusion-transmitted viral infections. The Retrovirus Epidemiology Donor Study. New England Journal of Medicine, 1996, 334:1685-1690.

28. Hyams KC et al. Geographic risk factors for viral hepatitis and cytomegalovirus infection among United States Armed Forces blood donors. Transfusion, 1992, 32:644-647.

29. Singh $S$ et al. Hepatitis B, C and human immunodeficiency virus infections in multiply-injected kala-azar patients in Delhi. Scandinavian Journal of Infectious Diseases, 2000, 32:3-6. 
30. Chowdhury A et al. Hepatitis $C$ virus infection in the genera population: a community-based study in West Bengal, India. Hepatology (Baltimore, Md.), 2003, 37:802-809.

31. Marx MA et al. The association of health-care use and hepatitis $C$ virus infection in a random sample of urban slum community residents in southern India. American Journal of Tropical Medicine and Hygiene, 2003, 68:258-262.

32. Van Doornum GJJ et al. Prevalence of hepatitis C virus infections among heterosexuals with multiple partners. Journal of Medical Virology, 1991, 35:22-27.
33. Brettler DB et al. The low risk of hepatitis $C$ virus transmission among sexual partners of hepatitis C-infected hemophilic males: an international, multicenter study. Blood, 1992, 80:540-543.

34. Hyams KC et al. Heterosexual transmission of viral hepatitis and cytomegalovirus among United States military personnel stationed in the western Pacific. Sexually Transmitted Diseases, 1993, 20:36-40. 